\title{
RESPONSE OF STRAWBERRY PLANTS TO SHORTENING DAY LENGTH , SHADING AND COLD STORAGE UNDER EGYPTIAN CONDITIONS
}

\author{
EL-SAWY,A.M., ${ }^{1}$, M. M. WADID ${ }^{1}$, U. A. EL-BEHAIRY ${ }^{2}$, \\ G. ZOCCHI ${ }^{3}$ AND A. F. ABOU-HADID ${ }^{4}$ \\ ${ }^{1}$ Central Laboratory of Agricultural Climate. Dokki, Giza, Egypt. \\ ${ }^{2}$ Horticulture Dept., of, Faculty. Agric, Ain-Shams Univ.Shoubra El- \\ Kheima, Cairo, Egypt. \\ 3 Plant Production, Faculty of Agriculture, Milan University, Italy \\ ${ }^{4}$ Agricultural Research Center.Giza, Egypt.
}

(Manuscript received 12 December, 2011)

\begin{abstract}
This experiment was performed in 2004/2005 and 2005/2006 seasons at El-Bosaly Protected Cultivation Experimental Site, of the Central Laboratory for Agricultural Climate (CLAC), $15 \mathrm{Km}$ west of Rosetta. The current study was conducted in open field to investigate the growth and productivity of strawberry plants under the shading and cold storage methods. Two strawberry cultivars were used, i.e., Camarosa (cv.) and Yael (cv.). Transplants were set up on 15 of March to 15 of September in both two seasons of 2004-2005 and 2005-2006, respectively under ElBosaly conditions. Seven treatments were used i.e., short day, $40 \%$ shading, $73 \%$ shading, three periods cold storage at $5 \mathrm{C}^{\circ}$, i.e., $(24 \mathrm{~h}, 48 \mathrm{~h}$ and $73 \mathrm{~h}$ ) and control. Results indicated that the application of $73 \%$ shading treatment was the most effective in reducing maximum and minimum of air temperature and radiation, followed by $40 \%$ shading, whereas, the highest value of maximum and minimum air temperature, radiation were observed in control treatment throughout the two growing seasons. In addition, $73 \%$ shading treatment produced the tallest plants and the highest number of leaves per plant and leaf area per plant. Moreover, flowering and chlorophyll in leaves were increased by application of short day treatment. Also, fruit characters such as average weight and number of fruits per plant were the highest values with $40 \%$ shading. Chemical components of fruits, i.e., T.S.S were increased with $73 \%$ shading treatment. When plants were grown under $40 \%$ shading treatment, followed by $73 \%$ shading, while cold storage for $72 \mathrm{~h}$ treatment gave the lowest values. Neither cultivars nor the interaction between cultivars and tested factors had any significant effects on many studied characters.
\end{abstract}

Key words: Strawberry, Photoperiod, Open field, Shading, Short day, Cold storage, Climatic conditions, Flowering and Total yield.

\section{INTRODUCTION}

Strawberry (Fragaria $X$ ananassa) has became one of the popular and favorite fruits to the Egyptian consumer due to many reasons such as, the highest nutritional value, reasonable prices, availability in the markets and the wide utility to using as fresh or processed. Moreover, strawberries were considered of great economic importance as 
a source of hard currency which is needed for our country because it had strong potentialities as an export commodity to the Arab and European markets.

Nursery of strawberry plants start from 15\March to 15\April. In May and Jun the climate is very hot and very height radians so the shading is very important to get good transplant and decrees temperature.

Strawberry plant needs chilling requirement to change buds from vegetation to flowering.

Shading has been used for many years to limit the amount of solar radiation entering greenhouses. Shade can be used over the top of the greenhouse (outside) or suspended inside the greenhouse above the crop. The most common materials are polypropylene, polyethylene, polyester, and theran, although cheese cloth and tobacco netting can also be used.

Using shade screen improved greenhouse climate; vapor pressure deficit and air temperature. This improvement implied a 36 per cent reduction of the total integral of the incident global radiation during the cropping cycle. Moreover, using shade screen during the summer growing season contributes to increase water and radiation use efficiencies and to improve the quality of fruits (Lorenzo et al., 2003). Although, shade is the most common suggested solution to overcome the effect of high temperature, Russo (1993) reported that shade inconsistently affect tomato yield.

Accordingly, this study aimed to investigate the effect of shading, cold storage and short day on the growth and yield of strawberry plants.

\section{MATERIALS AND METHODS}

The experiment was performed in 2004/2005 and 2005/2006 seasons at ElBosaly Protected Cultivation Experimental Site, of the Central Laboratory for Agricultural Climate (CLAC), $15 \mathrm{Km}$ west of Rosetta. The soil was sandy with $\mathrm{pH}$ of 7.89 and Ec of $1.34 \mathrm{~mm}$-hos. Two short day strawberry cultivars were used, i.e., Camarosa (cv.) and Yael (cv.). Transplants were set up on 15 of March to 15 September in both two seasons of 2004-2005 and 2005-2006, respectively.

Transplants were transplanted into open field on 15 of September to 1 March, which put into ridges 1 meter plant distances were $25 \mathrm{~cm}$.

\section{The experimental treatments:}

\section{Short day.}

Transplants of strawberry were covered by using black cloth from 1of May to 14 of September in both seasons. Cover was applied for 16 hours a day started at 4 pm: 8 am.

\section{Shading $\mathbf{7 3} \%$.}

Transplants of strawberry were covered by using black plastic net after 45 days form transplanting 1of May to 14 of September in both seasons all the day. 


\section{Shading 40\%.}

Transplants of strawberry were covered by using black plastic net after 45 days form transplanting 1of May to 14 of September in both seasons all the day.

\section{Cold storage at $\mathbf{2 4} \mathrm{h}$.}

150 daughter plants were potted in plastic cups $(150 \mathrm{ml})$ which separated from the mother plant after 20 day, and then three chilling treatments were applied as storage at $5 \mathrm{C}^{\circ} 24 \mathrm{~h}$ before transplanting.

\section{Cold storage at $48 \mathrm{~h}$.}

150 daughter plants were potted in plastic cups $(150 \mathrm{ml})$ which separated from the mother plant after 20 day, and then chilling treatments was applied by cold storage at $5 \mathrm{C}^{\circ}$ for $48 \mathrm{~h}$ before transplanting.

\section{Cold storage at $72 \mathrm{~h}$.}

150 daughter plants were potted in plastic cups $(150 \mathrm{ml})$ which separated from the mother plant after 20 day, and then three chilling treatments were applied as storage at $5 \mathrm{C}^{\circ} 72 \mathrm{~h}$ before transplanting.

\section{Control.}

Normal transplant were transplanted according to Ministry of Agriculture recommendation.

\section{Experimental design and the statistcal analysis :}

The experiment was arranged by applying the split plot design with three replicates. The cultivars were arranged in the main plots, whereas the treatments were arranged in the sub plots all obtained data were analyzed as reported by Snedecor and Cochran (1980).

\section{Data recorded:}

Number of leaves per plant, total plant fresh and dry weight and flowering were recorded. Total chlorophyll was measured in leaves by using digital chlorophyll meter (model Minolta Chlorophyll Meter SPAD-501). Early (after two harvests) and total yields were recorded.

\section{RESULTS AND DISCUSSION}

\section{Climatic data:}

The greatest values of maximum and minimum air temperatures and radiation, in general, were detected in control treatment followed by $40 \%$ shading treatment (Figs. 1, 2, 3 and 4). However, the lowest maximum and minimum air temperatures and radiation were found when using $73 \%$ shading. In other words, the $73 \%$ shading treatment reduced the temperature and radiation values compared to the other treatments. These results are in agreement with those reported by Verldot et al. (1985), Abreu et al. (2001)and Kittas et al. (2009). 

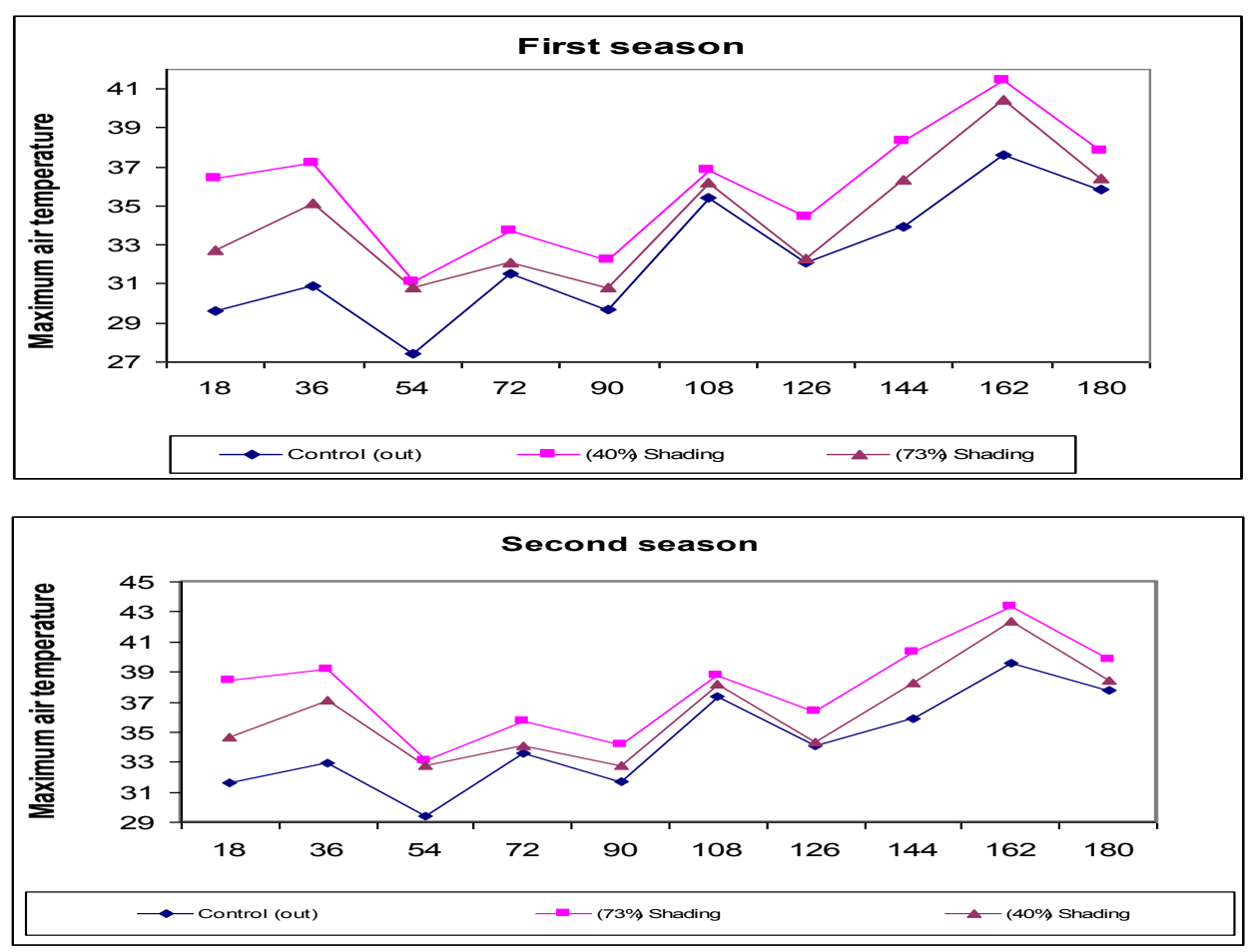

Figure 1. Maximum air temperature at El-Bosaly site during 2005 and 2006 seasons
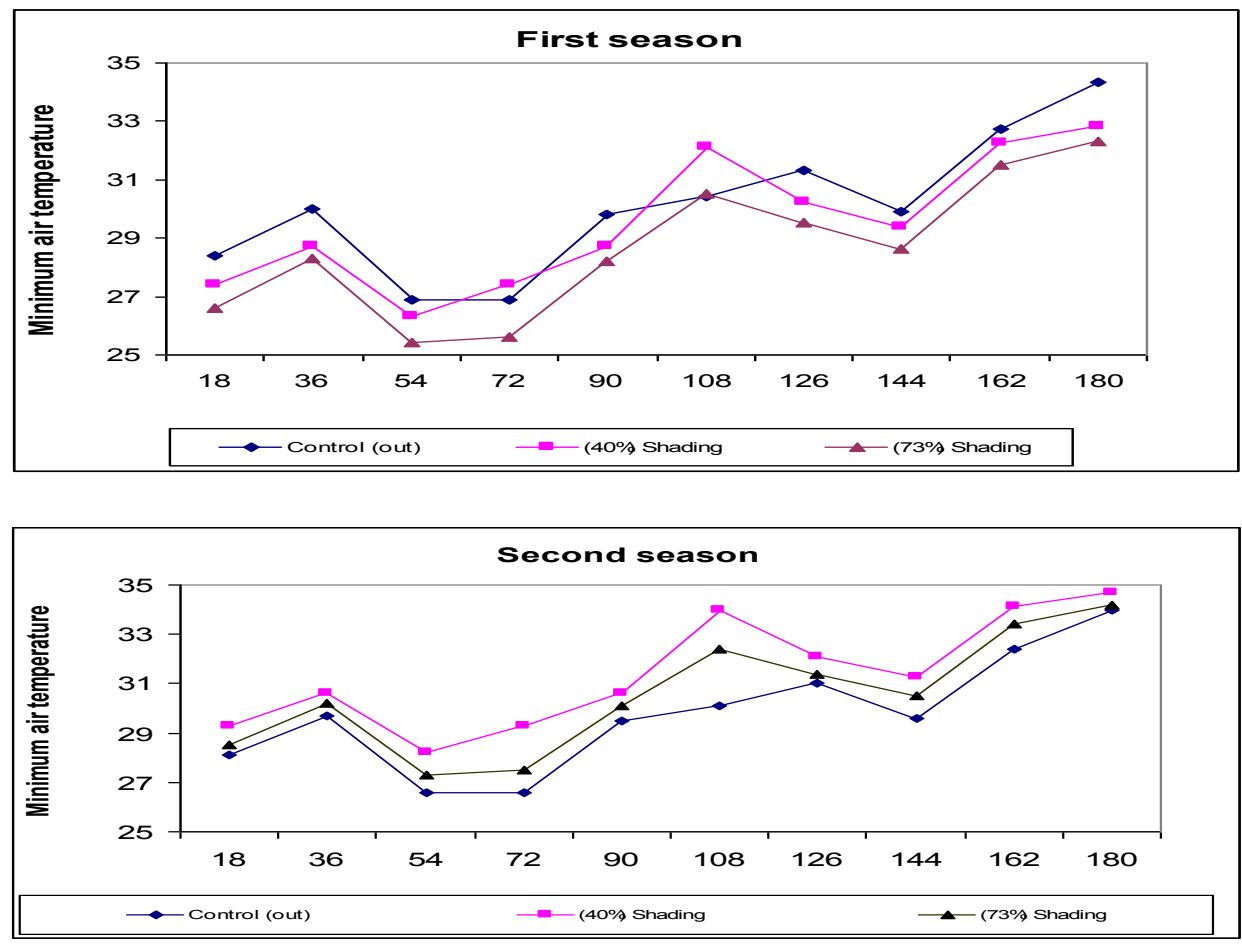

Figure 2. Minimum air temperature at El-Bosaly site during 2005 and 2006 seasons. 

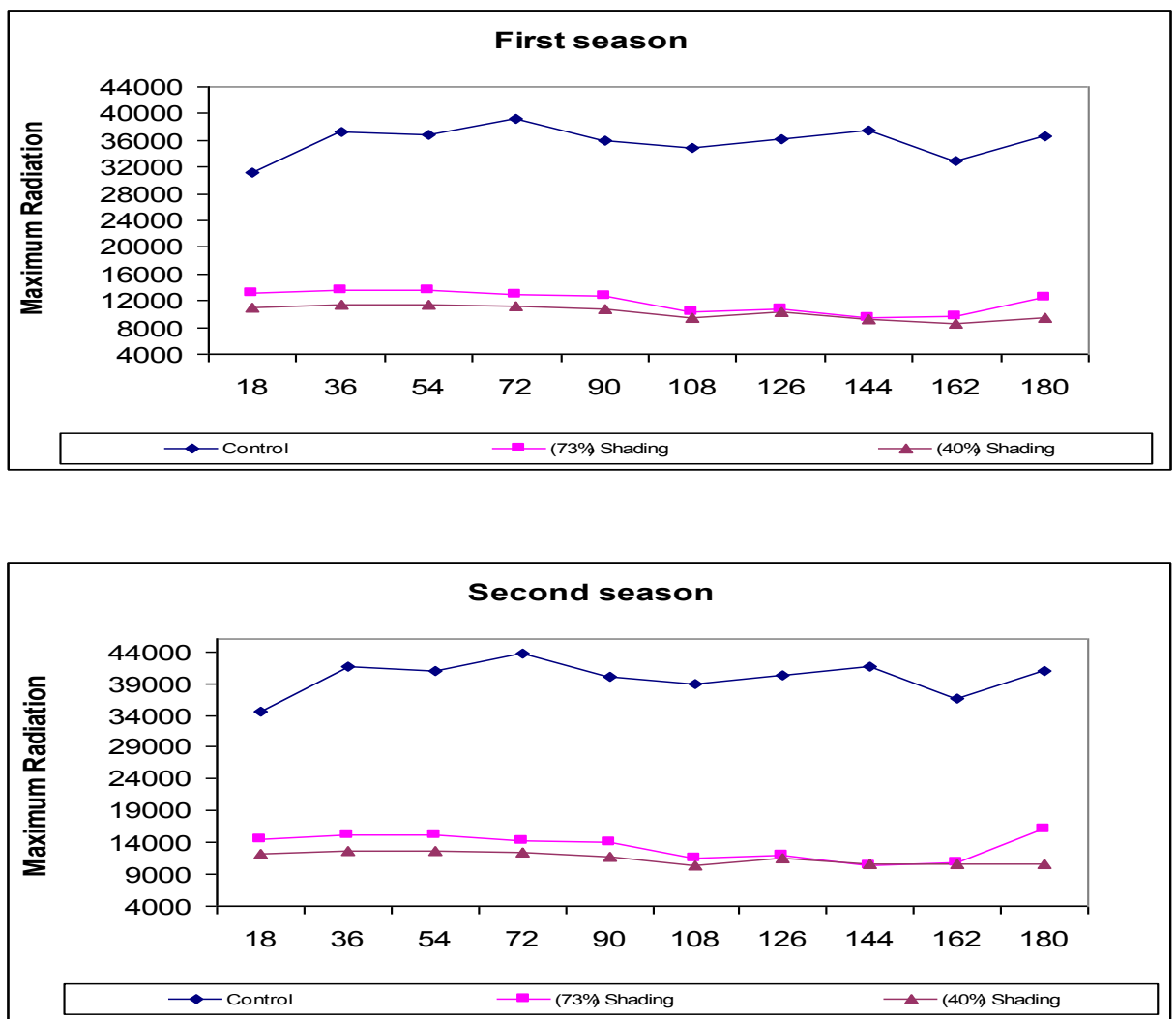

Figure 3. Maximum radiation at El-Bosaly site during 2005 and 2006 seasons.
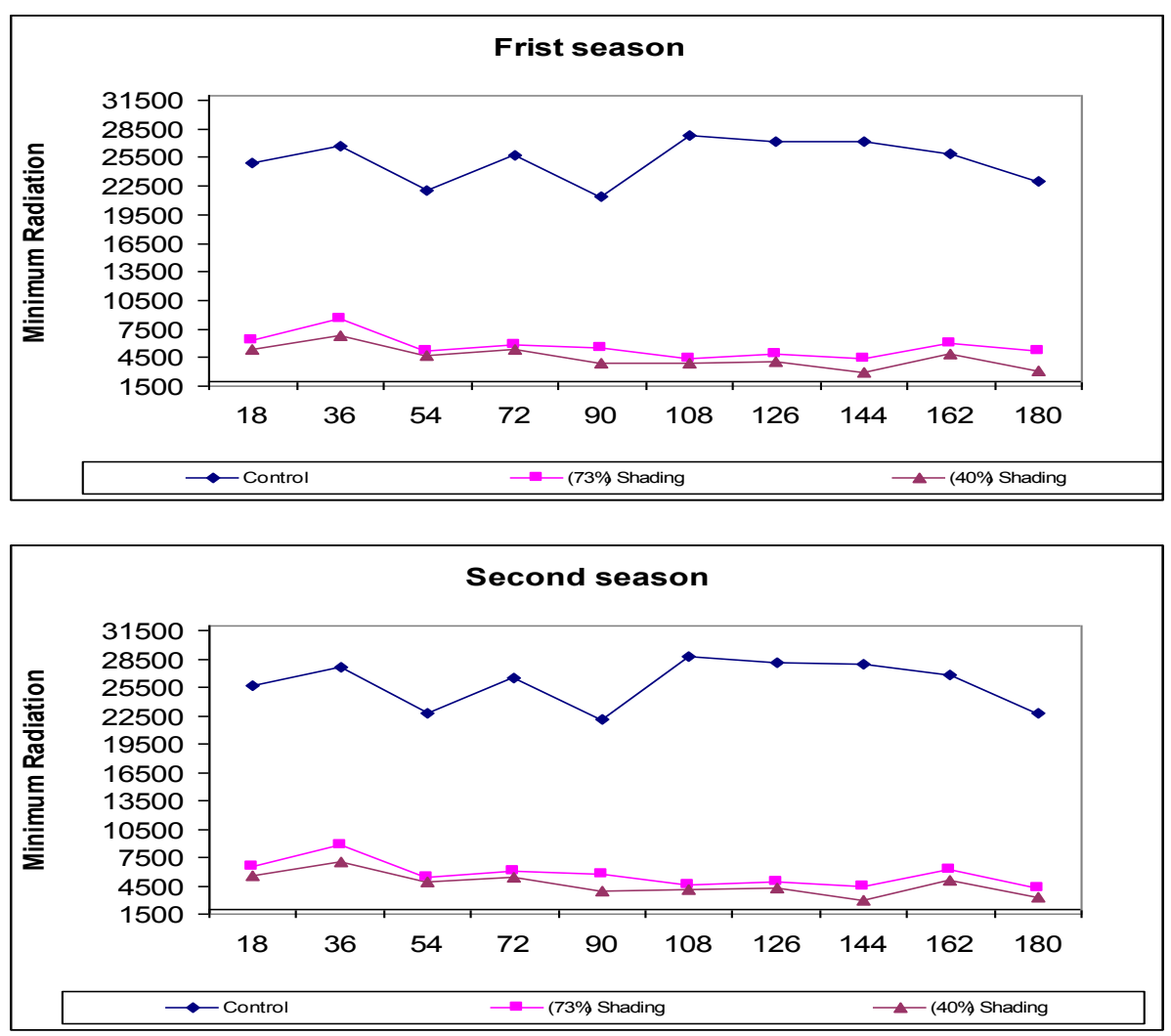

Figure 4. Minimum radiation at El-Bosaly site during 2005 and 2006 seasons 


\section{Vegetative growth:}

\section{Number of leaves per plant:}

Shading treatments recorded the highest number of leaves per plant, whereas, plants received cold storage for $72 \mathrm{~h}$ gave the lowest values Table (1). It was noticed also that there were insignificant differences for leaf number between the two studied cultivars after 4 months from transplanting. In other words, the most favorable treatment for stimulation the number of leaves per plant was the application of $40 \%$ shading, in general, all over the both growing seasons. These results are in harmony with those of Adam et al. (2002).

Results showed also that the interaction had not any significant influences on number of leaves per plant all over the two growing seasons.

Table 1. Effect of shading rates, short day, cold storage treatments and cultivars on number of leaves per plant after 4 months from transplanting of strawberry plants during the growing seasons of 2004/2005 and 2005/2006.

\begin{tabular}{|c|c|c|c|c|c|c|c|c|}
\hline \multicolumn{9}{|c|}{ 2004-2005 } \\
\hline \multicolumn{9}{|c|}{ Treatments } \\
\hline \multirow[t]{2}{*}{ Cultivars } & \multirow[t]{2}{*}{ Control } & \multicolumn{2}{|c|}{ Shading rate } & \multirow{2}{*}{$\begin{array}{c}\text { Short } \\
\text { day } \\
6 \mathrm{H}\end{array}$} & \multicolumn{3}{|c|}{ Cold storage days } & \multirow[t]{2}{*}{ Mean } \\
\hline & & $40 \%$ & $73 \%$ & & "1" & "2" & "3" & \\
\hline Camarosa & 23.33 & 31.53 & 28.17 & 29.92 & 21.75 & 14.50 & 15.67 & 32.97 \\
\hline YAEL & 17.17 & 19.58 & 21.33 & 18.58 & 13.33 & 15.00 & 12.00 & 23.40 \\
\hline Mean & 20.25 & 25.56 & 24.75 & 24.25 & 17.54 & 14.75 & 13.83 & \\
\hline \multicolumn{9}{|l|}{ L.S.D 0.05} \\
\hline Cultivars & N.S & & & & & & & \\
\hline Treatments & 1.88 & & & & & & & \\
\hline Interaction & N.S & & & & & & & \\
\hline \multicolumn{9}{|c|}{$2005-2006$} \\
\hline Camarosa & 24.50 & 33.10 & 29.58 & 31.41 & 22.84 & 15.23 & 16.45 & 34.62 \\
\hline YAEL & 18.20 & 20.76 & 22.61 & 19.70 & 14.13 & 15.90 & 12.72 & 24.80 \\
\hline Mean & 21.35 & 26.93 & 26.09 & 25.56 & 18.49 & 15.56 & 14.59 & \\
\hline \multicolumn{9}{|l|}{ L.S.D 0.05} \\
\hline Cultivars & N.S & & & & & & & \\
\hline Treatments & 1.98 & & & & & & & \\
\hline Interaction & N.S & & & & & & & \\
\hline
\end{tabular}




\section{Plant fresh weight:}

No significant differences in plant fresh weight were obtained as a result of cultivars during both seasons Table (2).

Plants grown under $40 \%$ shading treatment produced the highest Plants fresh weight compared to the other treatments. Similar results were observed in second season. Where, cold storage for $24 \mathrm{~h}$ and $48 \mathrm{~h}$ gave the lowest plant fresh weight.

It was noticed also that there were insignificant differences for plant fresh weight in the interaction among treatments and cultivars.

The highest plant fresh weight interaction was observed with $40 \%$ shading treatment and Camarosa c.v., while cold storage for 24 h, with, YAEL C.v showed the lowest values.

This was true during both two seasons. Similar results were reported by Adam et al. (2002), Liu et al. (2002) and Paez et al. (2000).

Table 2. Effect of shading rates, short day, cold storage treatments and cultivars on average fruit fresh weight $(\mathrm{g})$ of strawberry plants during the growing seasons of 2004/2005 and 2005/2006.

\begin{tabular}{|c|c|c|c|c|c|c|c|c|}
\hline \multicolumn{9}{|c|}{ 2004-2005 } \\
\hline \multicolumn{9}{|c|}{ Treatments } \\
\hline \multirow[t]{2}{*}{ Cultivars } & \multirow[t]{2}{*}{ control } & \multicolumn{2}{|c|}{ Shading rate } & \multirow{2}{*}{$\begin{array}{c}\text { Short day } \\
6 \mathrm{H}\end{array}$} & \multicolumn{3}{|c|}{ Cold storage } & \multirow[t]{2}{*}{ Mean } \\
\hline & & $40 \%$ & $73 \%$ & & 1day & 2day & 3day & \\
\hline Camarosa & 24.78 & 20.11 & 24.00 & 13.44 & 20.11 & 17.56 & 14.33 & 26.867 \\
\hline YAEL & 17.00 & 29.22 & 25.22 & 22.56 & 28.22 & 13.89 & 15.56 & 30.33 \\
\hline Mean & 20.89 & 24.67 & 24.61 & 18.00 & 24.17 & 15.72 & 14.94 & \\
\hline \multicolumn{9}{|l|}{ L.S.D $D_{0.05}$ for } \\
\hline Cultivars & N.S & & & & & & & \\
\hline Treatments & 1.13 & & & & & & & \\
\hline Interaction & 2.27 & & & & & & & \\
\hline \multicolumn{9}{|c|}{$2005-2006$} \\
\hline Camarosa & 26.02 & 21.12 & 25.20 & 14.12 & 21.12 & 18.43 & 15.05 & 28.210 \\
\hline YAEL & 18.02 & 30.98 & 26.74 & 23.91 & 29.92 & 14.72 & 16.49 & 32.15 \\
\hline Mean & 22.02 & 26.05 & 25.97 & 19.01 & 25.52 & 16.58 & 15.77 & \\
\hline \multicolumn{9}{|l|}{ L.S.D $D_{0.05}$ for } \\
\hline Cultivars & N.S & & & & & & & \\
\hline Treatments & 1.19 & & & & & & & \\
\hline Interaction & 2.39 & & & & & & & \\
\hline
\end{tabular}




\section{Plant dry weight:}

Plant dry weight was not affected by short day, shading and cold storage treatments or the interaction between all treatments and the two cultivars (Table 3).

The two cultivars, there was high significance herein. Camarosa c.v. recorded greater values of dry weight of leaves than c.v Yael.

The obtained results are not agree with those of Smith et al. (1984), Hamamoto et al. (2000) and Adam et al. (2002).

From the aforementioned data on plant growth, it could conclud that the applied $40 \%$ shading treatment was the most favorable for stimulating plant growth.

Table 3. Effect of shading rates, short day, cold storage treatments and cultivars on plant dry weight $(\mathrm{g})$ of strawberry plants during the growing seasons of 2004/2005 and 2005/2006.

\begin{tabular}{|c|c|c|c|c|c|c|c|c|c|c|}
\hline \multicolumn{11}{|c|}{ 2004-2005 } \\
\hline \multicolumn{11}{|c|}{ Treatments } \\
\hline \multirow[t]{2}{*}{ Cultivars } & \multirow[t]{2}{*}{ control } & \multicolumn{2}{|c|}{ Shading rate } & \multirow{2}{*}{$\begin{array}{l}\text { Short } \\
\text { day } \\
6 \mathrm{H}\end{array}$} & \multicolumn{5}{|c|}{ Cold storage days } & \multirow[b]{2}{*}{ Mean } \\
\hline & & $40 \%$ & $73 \%$ & & "1" & \multicolumn{2}{|c|}{ "2" } & \multicolumn{2}{|c|}{ "3" } & \\
\hline Camarosa & 18.17 & 21.33 & 19.55 & 19.28 & 19.39 & \multicolumn{2}{|c|}{19.11} & \multicolumn{2}{|c|}{19.83} & 27.33 \\
\hline YAEL & 19.85 & 26.47 & 23.27 & 19.57 & 21.05 & \multicolumn{2}{|c|}{16.33} & \multicolumn{2}{|c|}{19.33} & 29.17 \\
\hline Mean & 19.01 & 23.90 & 21.41 & 19.42 & 20.22 & & & \multicolumn{2}{|c|}{19.58} & \\
\hline \multicolumn{11}{|l|}{ L.S.D 0.05 for } \\
\hline Cultivars & 0.30 & & & & & & & & & \\
\hline Treatments & N.S & & & & & & & & & \\
\hline Interaction & N.S & & & & & & & & & \\
\hline \multicolumn{11}{|c|}{$2005-2006$} \\
\hline Camarosa & 18.97 & 22.38 & 20.39 & 20.25 & 20 & & 20.0 & & 20.84 & 28.67 \\
\hline YAEL & 21.25 & 28.31 & 25.05 & 20.96 & 22 & & 17. & & 20.67 & 31.18 \\
\hline Mean & 20.11 & 25.34 & 22.72 & 20.60 & 21 & & 18.7 & & 20.76 & \\
\hline \multicolumn{11}{|l|}{ L.S.D 0.05} \\
\hline Cultivars & 0.37 & & & & & & & & & \\
\hline Treatments & N.S & & & & & & & & & \\
\hline Interaction & N.S & & & & & & & & & \\
\hline
\end{tabular}




\section{Chlorophyll content of leaves}

The statistical analysis showed that plants grown under short day treatment had the highest total chlorophyll readings in their leaves during the two growing seasons. However, application cold storage treatments recorded the lowest total chlorophyll readings Table (4). These results were true in both growing seasons. Similar results were reported by Goma (1966), Moustafa (1991), Shehata, (1996), and Adam et al. (2002).

No, significant effects on total chlorophyll were noticed for both Camarosa and Yael cultivars.

Regarding the interaction between the tested treatments and cultivars it was significant. The best treatment was obtained with short day and both cultivars which significantly increased than any other interaction treatments.

Table 4. Effect of shading rates, short day, cold storage treatments and cultivars on number. of days until flowering of strawberry plants during the growing seasons of 2004/2005 and 2005/2006.

\begin{tabular}{|c|c|c|c|c|c|c|c|c|}
\hline \multicolumn{9}{|c|}{ 2004-2005 } \\
\hline \multicolumn{9}{|c|}{ Treatments } \\
\hline \multirow[t]{2}{*}{ Cultivars } & \multirow[b]{2}{*}{ control } & \multicolumn{2}{|c|}{ Shading rate } & \multirow{2}{*}{$\begin{array}{c}\text { Short } \\
\text { day } \\
6 \mathrm{H} \\
\end{array}$} & \multicolumn{3}{|c|}{ Cold storage days } & \multirow[t]{2}{*}{ Mean } \\
\hline & & $40 \%$ & $73 \%$ & & "1" & "2" & "3" & \\
\hline Camarosa & 65 & 72.3 & 72 & 64.6 & 62.6 & 62.3 & 60 & 65.54 \\
\hline YAEL & 64.87 & 70.71 & 71.06 & 62.9 & 61.7 & 61.3 & 58.07 & 64.37 \\
\hline Mean & 64.935 & 71.505 & 71.53 & 63.75 & 62.15 & 61.8 & 59.035 & \\
\hline \multicolumn{9}{|l|}{ L.S.D 0.05} \\
\hline Cultivars & N.S & & & & & & & \\
\hline Treatments & 1.75 & & & & & & & \\
\hline Interaction & N.S & & & & & & & \\
\hline \multicolumn{9}{|c|}{$2005-2006$} \\
\hline Camarosa & 65.8 & 73.4 & 72.7 & 65.8 & 63.22 & 63.5 & 60.6 & 66.43 \\
\hline YAEL & 66.1 & 71.41 & 71.7 & 63.5 & 62.9 & 61.9 & 58.6 & 65.15 \\
\hline Mean & 65.95 & 72.405 & 72.2 & 64.65 & 63.06 & 62.7 & 59.6 & \\
\hline \multicolumn{9}{|l|}{ L.S.D 0.05} \\
\hline Csultivars & N.S & & & & & & & \\
\hline Treatments & 2.03 & & & & & & & \\
\hline Interaction & N.S & & & & & & & \\
\hline
\end{tabular}

\section{Flowering:}

Generally, using the shading treatments gave the highest number of days for flowering followed by control treatment. While, plants grown under the cold storage 
for $72 \mathrm{~h}$ treatment gave the lowest number of days for up to flowering (Table 5). This result was true in both seasons. These findings are in agreement with those of Shehata (1996), Aldazabal and Zamora (2000) and Liu et al. (2002) .

It was noticed also that there were insignificant differences in flowering periods between the two studied cultivars or among the interaction treatments. This was true during both growing seasons.

Table 5. Effect of shading rates, short day, cold storage treatments and cultivars on total chlorophyll reading of strawberry plants during the growing seasons of 2004/2005 and 2005/2006.

\begin{tabular}{|c|c|c|c|c|c|c|c|c|}
\hline \multicolumn{9}{|c|}{ 2004-2005 } \\
\hline \multicolumn{9}{|c|}{ Treatments } \\
\hline \multirow[t]{2}{*}{ Cultivars } & \multirow[b]{2}{*}{ control } & \multicolumn{2}{|c|}{ Shading rate } & \multirow{2}{*}{$\begin{array}{c}\text { Short day } \\
6 \mathrm{H} \\
\end{array}$} & \multicolumn{3}{|c|}{ Cold storage days } & \multirow[t]{2}{*}{ Mean } \\
\hline & & $40 \%$ & $73 \%$ & & "1" & "2" & "3" & \\
\hline Camarosa & 45.76 & 55.9 & 57.93 & 59 & 44.38 & 43.79 & 43.3 & 50.00 \\
\hline YAEL & $\varepsilon \pi, r r$ & 56.59 & 58.64 & 59.72 & 44.93 & 44.34 & 43.84 & 50.62 \\
\hline Mean & 46.04 & 56.24 & 58.28 & 59.36 & 44.65 & 44.06 & 43.57 & \\
\hline L.S.D 0.05 & & & & & & & & \\
\hline Cultivars & 12.6 & & & & & & & \\
\hline Treatments & N.S & & & & & & & \\
\hline Interaction & 14.6 & & & & & & & \\
\hline \multicolumn{9}{|c|}{$2005-2006$} \\
\hline Camarosa & 46.3 & 56.52 & 59.6 & 59.11 & 45.31 & 44.6 & 44.2 & 50.80 \\
\hline YAEL & $\leq \uparrow, \wedge \vee$ & 57.15 & 60.39 & 59.89 & 45.48 & 44.8 & 44.7 & 51.32 \\
\hline Mean & 46.58 & 56.83 & 59.99 & 59.5 & 45.39 & 44.7 & 44.45 & \\
\hline \multicolumn{9}{|l|}{ L.S. $D_{0.05}$} \\
\hline Csultivars & 11.47 & & & & & & & \\
\hline Treatments & N.S & & & & & & & \\
\hline Interaction & 12.97 & & & & & & & \\
\hline
\end{tabular}

\section{Early and total yield:}

Application of short day, shading and cold storage treatments were significantly affect early and total yield per plant. All investigated shading treatments increased the early and total yield. The most effective treatment in enhancing the early and total yield 
was $40 \%$ shading. Whereas, cold storage for $72 \mathrm{~h}$ treatment decreased the early and total yield per plant (Table 6 and 7).

Cultivars did not reflect any significant effect on the early and total yield. The interaction between treatments and cultivars data indicated that $40 \%$ shading treatment with both cultivars produced strawberry having greatest early and total yield, while, cold storage for $48 \mathrm{~h}$ recorded the lowest values. These results were detected in both growing seasons.

The obtained results are in harmony with those of Smith et al. (1984), El-Aidy (1984), Aldazabal and Zamora (2000), Liu et al. (2002), and Kittas et al. (2009).

Table 6. Effect of shading rates, short day, cold storage treatments and cultivars on early yield per plant $(\mathrm{g})$ of strawberry plants during the growing seasons of 2004/2005 and 2005/2006.

\begin{tabular}{|c|c|c|c|c|c|c|c|c|}
\hline \multicolumn{9}{|c|}{ 2004-2005 } \\
\hline \multicolumn{9}{|c|}{ Treatments } \\
\hline \multirow[t]{2}{*}{ Cultivars } & \multirow[b]{2}{*}{ control } & \multicolumn{2}{|c|}{ Shading rate } & \multirow{2}{*}{$\begin{array}{c}\text { Short } \\
\text { day } \\
6 \mathrm{H} \\
\end{array}$} & \multicolumn{3}{|c|}{ Cold storage days } & \multirow[t]{2}{*}{ Mean } \\
\hline & & $40 \%$ & $73 \%$ & & "1" & "2" & "3" & \\
\hline Camarosa & 230.42 & 225.2 & 237.36 & 167.14 & 183.02 & 173.59 & 102.1 & 188.40 \\
\hline YAEL & 225 & 278.05 & 236.08 & 182.55 & 151.23 & 87.92 & 96.41 & 179.60 \\
\hline Mean & 227.71 & 251.62 & 236.72 & 174.84 & 167.12 & 130.75 & 99.25 & \\
\hline \multicolumn{9}{|l|}{ L.S.D $D_{0.05}$} \\
\hline Cultivars & N.S & & & & & & & \\
\hline Treatments & 10.1 & & & & & & & \\
\hline Interaction & 18.9 & & & & & & & \\
\hline \multicolumn{9}{|c|}{ 2005-2006 } \\
\hline Camarosa & 242.75 & 273.23 & 253.7 & 178.75 & 195.8 & 147.24 & 121.1 & 201.79 \\
\hline YAEL & 230 & 360.41 & 348.7 & 191.81 & 161.75 & 94.99 & 102.88 & 212.93 \\
\hline Mean & 236.37 & 316.82 & 301.2 & 185.28 & 178.77 & 121.11 & 111.99 & \\
\hline \multicolumn{9}{|l|}{ L.S.D $D_{0.05}$} \\
\hline Csultivars & N.S & & & & & & & \\
\hline Treatments & 9.89 & & & & & & & \\
\hline Interaction & 19.8 & & & & & & & \\
\hline
\end{tabular}


Table 7. Effect of shading rates, short day, cold storage treatments and cultivars on total yield per plant $(\mathrm{g})$ of strawberry plants during the growing seasons of 2004/2005 and 2005/2006.

\begin{tabular}{|c|c|c|c|c|c|c|c|c|}
\hline \multicolumn{9}{|c|}{ 2004-2005 } \\
\hline \multicolumn{9}{|c|}{ Treatments } \\
\hline \multirow{2}{*}{ Cultivars } & \multirow[t]{2}{*}{ Control } & \multicolumn{2}{|c|}{ Shading rate } & \multirow{2}{*}{$\begin{array}{c}\text { Short day } \\
6 \mathrm{H} \\
\end{array}$} & \multicolumn{3}{|c|}{ Cold storage } & \multirow[t]{2}{*}{ Mean } \\
\hline & & $40 \%$ & $73 \%$ & & 1day & 2day & 3day & \\
\hline Camarosa & 921.69 & 1021.06 & 949.44 & 668.57 & 732.08 & 550.39 & 408.42 & 1050.33 \\
\hline YAEL & 900.75 & 1112.20 & 944.33 & 730.22 & 604.93 & 351.68 & 385.65 & 920.35 \\
\hline Mean & 697.22 & 1066.63 & 946.89 & 699.40 & 668.50 & 451.03 & 397.03 & \\
\hline L.S.D ${ }_{0.05}$ for & & & & & & & & \\
\hline Cultivars & N.S & & & & & & & \\
\hline Treatments & 36.53 & & & & & & & \\
\hline Interaction & 73.03 & & & & & & & \\
\hline \multicolumn{9}{|c|}{$2005-2006$} \\
\hline Camarosa & 971.09 & 1092.95 & 1015.11 & 715.10 & 783.38 & 588.97 & 437.12 & 1120.75 \\
\hline YAEL & 900.14 & 1201.64 & 994.82 & 767.25 & 647.00 & 379.98 & 411.53 & 981.27 \\
\hline Mean & 737.62 & 1147.29 & 1004.96 & 741.17 & 715.19 & 484.48 & 424.33 & \\
\hline \multicolumn{9}{|l|}{ L.S.D $D_{0.05}$ for } \\
\hline Cultivars & N.S & & & & & & & \\
\hline Treatments & 39.66 & & & & & & & \\
\hline Interaction & 79.32 & & & & & & & \\
\hline
\end{tabular}

\section{REFERENCES}

1. Abreu, M. J., V. C. Ferreia, A. C. Vargues and J. F. Meneses. 2001. Evaluation of greenhouse structures for tomato spring crops in Enter Douro Eminho region of Porugal. Acta Hort. 559: 169-175.

2. Adam, S. F., A. M. Abdalla and A. F. Abou-Hadid. 2002. Effect of shading on the growth and productivity of some tomato cultivars in the summer season. Egypt. J. Hort. 29 (2): 271-280.

3. Aldazabal, M. and R. Zamora. 2000. Flowering and fruiting of tomatoes (Lycopersicum esculentum Willd.) under full sunlight or shading, grown in the summer. Alimentaria. 37(317): 21-124. 
4. El-Aidy, F. 1984. Research on the use of plastics and shade nets on the production of some vegetable crops in Egypt. Acta-Horticulturae. 154: 109-113.

5. Goma, H. M. 1966. Effect of shading, pruning staking and plant population on the growth and chemical contents of tomato plants. Ph. D. Thesis, Fac. Agric., Ain Shams University, Egypt.

6. Hamamoto, H. Y. Shishido, T. Uchiumi and H. Kumakura. 2000. Effects of low light intensity on growth, photosynthesis and distribution of photo assimilates in tomato plants. Environment Control in Biology. 38 (2): 63-69.

7. Kittas, C., N. Rigakis, N. Katsoulas and T. Bartzanas. 2009. Influence of shading screens on microclimate, growth and productivity of tomato. Acta Hort. 807: 235-243.

8. Liu, X. Z., S. Z. Kang and J. H. Zhang. 2002. Yield and photosynthetic responses of tomato (Lycopersicon esculentum) to shading at different growth stages. Indian Journal of Agricultural Sciences. 72 (2): 106-108.

9. Lorenzo, P., M. C. Sánchez-Guerrero, E. Medrano, M. L. García, I. Caparrós and M. Giménez. 2003. Greenhouse mobile shading: effect on microclimate, water use efficiency and yield of a tomato crop grown under different salinity levels of the nutrient solution. Acta Horticulturae 609: 181-186.

10. Moustafa, S. M. S. 1991. Effect of shading on growth, yield and fruit quality of tomato plant. M. Sc. Thesis, Fac. Agric., Ain Shams University, Egypt.

11. Paez, A., V. Paz and J. C. Lopez. 2000. Growth and physiological responses of tomato plants Cv. Rio Grande during May to July season. Effect of shading. Revista de la Facultad de Agronomia, Universidad del Zulia. 17: (2) 173-184.

12. Russo, V. M. 1993. Shading of tomato plants inconsistently affects fruit yield. Hortscience. 28: 1133-1133.

13. Shehata, S. M. 1996. Effect of shading and some chemical treatments on productivity of tomato in summer season. Ph. D. Thesis, Fac. Agric., Ain Shams University, Egypt.

14. Smith, I. E., M. J. Savage and P. Mills. 1984. Shading effects on greenhouse tomatoes and cucumbers. Acta Hort. 148 (II): 491-500.

15. Snedecor, G. W. and W. G. Cochran. 1980. Statistical Methods. $7^{\text {th }}$ (Ed.), Iowa State Univ. Press, Iowa, USA.

16. Verlodt, H., S. Baeten, S. Elfahem and Y. Harbaui. 1985. Influence of different static aeration systems on the diurnal climate under PE greenhouse. Acta Hort. 170: $153-172$. 


\section{استجابة نباتات الفراولة لتقصير التهار والتظليل والتخزين المبرد تحت الظروف المصرية}

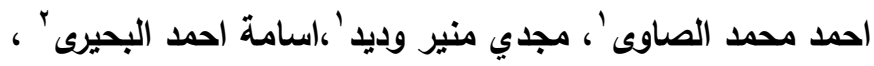

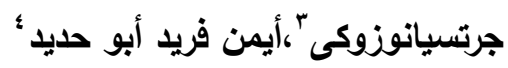

$$
\begin{aligned}
& \text { المعدل المركزي للمناخ الزراعي - مركز البحوث الزراعية - دقي - جيزة - مصر. } \\
& \text { r قسم البساتين - كلبة الزراعة - جامعة عين شعس- شبر الخبية - القاهة - مصر. } \\
& \text { r قسم النبات جامعة ميلانو - ايطاليا. } \\
& \text { ع مركز البحوث الزراعية - جيزة - مصر. }
\end{aligned}
$$

نم أجراء تجربنين حقلينين خلال موسمى 2004/2005 و 2005/2006 بموقع البوصيلي للزراعات

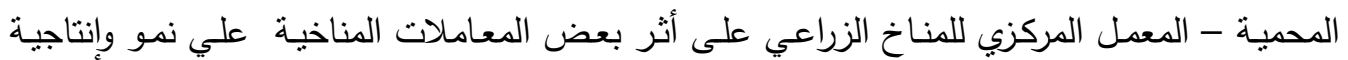

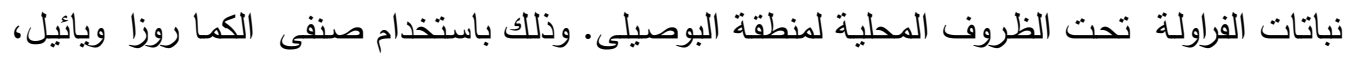

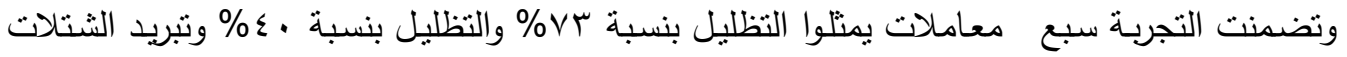

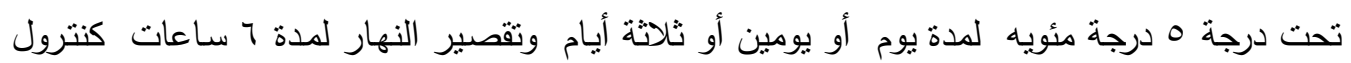

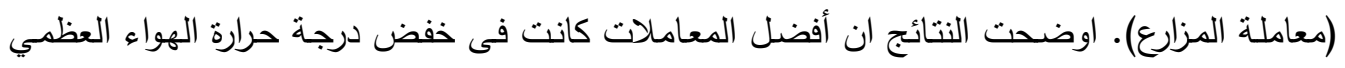

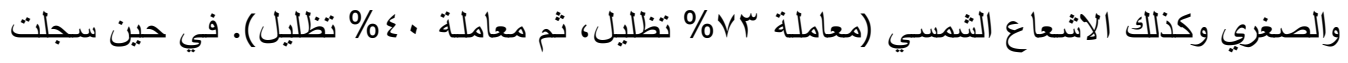

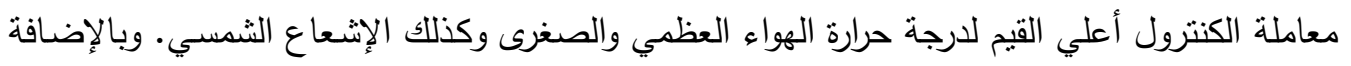

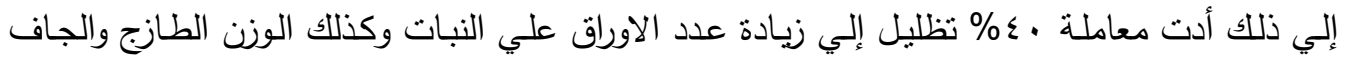
اللنبات. وقد لوحظ التبكير في الازهار وزيادة محتوي الاوراق من الكلوروفيل مع تقصير عدد ساعات

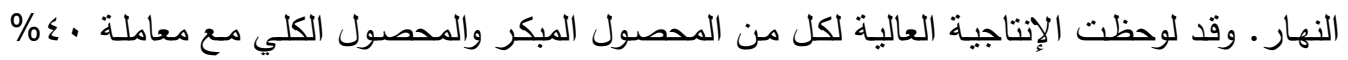
تظليل. في حين أعطت معاملة الكنترول (المقارنة) أقل إنتاجية للححصول المبكر والكلي. 